CLINICAL STUDY

\title{
Genetic variation in adipokine genes and risk of colorectal cancer
}

\author{
Sonali Pechlivanis ${ }^{1}$, Justo Lorenzo Bermejo ${ }^{1,2}$, Barbara Pardini $^{3}$, Alessio Naccarati ${ }^{3}$, Ludmila Vodickova ${ }^{3,4}$, \\ Jan Novotny ${ }^{5}$, Kari Hemminki ${ }^{1,6}$, Pavel Vodicka ${ }^{3}$ and Asta Försti ${ }^{1,6}$ \\ ${ }^{1}$ Division of Molecular Genetic Epidemiology CO50, German Cancer Research Center (DKFZ), Im Neuenheimer Feld 580, 69120 Heidelberg, Germany, \\ ${ }^{2}$ Institute of Medical Biometry and Informatics (IMBI), University of Heidelberg, Im Neuenheimer Feld 305, 69120 Heidelberg, Germany, ${ }^{3}$ Department of \\ Molecular Biology of Cancer, Institute of Experimental Medicine, Academy of Science of Czech Republic, Videnska 1083, 14220 Prague 4, Czech Republic, \\ ${ }^{4}$ National Institute of Public Health, Centre of Occupational Health, Srobarova, 10042 Prague 2, Czech Republic, ${ }^{5}$ Department of Oncology, General \\ Teaching Hospital, U Nemocnice 2, 12808 Prague 2, Czech Republic and ${ }^{6}$ Karolinska Institute, Center for Family and Community Medicine, Alfred Nobels \\ allé 12, 14183 Huddinge, Sweden
}

(Correspondence should be addressed to A Försti; Email: a.foersti@dkfz.de)

\begin{abstract}
Objective: Obesity has been related to an increased risk of colorectal cancer (CRC). Adipokines produced by the adipose tissue are directly linked to obesity and may thus contribute to the pathogenesis of CRC. We hypothesized that potentially functional polymorphisms in the adipokine genes leptin (LEP), leptin receptor (LEPR), resistin (RETN), and adiponectin (ADIPOQ) may be associated with CRC.

Design and methods: We studied the association of four putatively functional single nucleotide polymorphisms (SNPs) with CRC risk using a hospital-based study design with 702 cases and 752 controls from the Czech Republic. We used likelihood ratio tests to select the best model to represent the relationship between genotypes and risk of CRC. Age-adjusted odds ratios (ORs) under the best model were calculated for each SNP. Previous genotyping data on insulin (INS)-related genes were used to explore interactions between genes in obesity- and diabetes-related pathways by using two independent methods, logistic regression, and multifactor-dimensionality reduction.

Results: A trend to associate between the RETN SNP rs1862513 (C-420G) and CRC risk was observed (per allele OR 1.18, 95\% confidence interval (0.99-1.40). Statistically, significant interactions were observed between the INS SNP rs3842754 (+1127INSPstI) genotypes and both the LEPR SNP rs1137101 (Q223R) and the ADIPOQ SNP rs266729 (C-11374G) genotypes.

Conclusions: Our results suggest that variants in the adipokine genes may affect CRC risk in combination with variants in diabetes-related genes.
\end{abstract}

European Journal of Endocrinology $160933-940$

\section{Introduction}

Obesity has been consistently associated with increased risk of cancer, including the risk of colorectal cancer (CRC) $(1,2)$. Both family-based and twin studies have indicated a strong heritable component for individual body mass index (BMI) $(3,4)$. The 2005 update of the human obesity gene map contains 253 quantitativetrait loci, and 22 gene associations, which have been replicated in at least five studies (5). Among these 22 genes are four adipokine genes, adiponectin (ADIPOQ), leptin (LEP), leptin receptor (LEPR), and resistin (RETN), which are expressed in and whose products are secreted by the adipose tissue. Adipokines can exert their biological actions on target cells by endocrine as well as by paracrine mechanisms. In addition to obesity, adipokines have been associated with several obesity-related disorders, such as type 2 diabetes, cardiovascular disease, inflammation, and CRC (6-9).

Plasma leptin levels are elevated in obesity and they increase with increasing fat mass (8). Leptin can also act as a mitogen, transforming factor or migration factor for many different cell types, including normal and neoplastic colon epithelial cells $(8,10,11)$. Several prospective case-control studies have associated increased leptin levels with increased CRC risk (12-15). Leptin exerts its physiological action through the leptin receptor, which is expressed in colon cancer cell lines as well as in human normal colonic tissue and adenomatous polyps $(10,11)$. Resistin levels are also increased in both genetic and diet-induced obesity in mice (16). Recently, increased resistin protein expression has been observed in CRC tissue compared with the paired normal tissue (17). In contrast to high 
leptin and resistin levels, low-adiponectin levels have been shown to associate with obesity and to confer a substantially increased risk for diabetes, cardiovascular diseases and several cancers, including CRC (6, 7, 18, 19), although in one study, no association with CRC was observed (20). However, a recent study suggests that the leptin/adiponectin ratio may be a better marker for factors of metabolic syndrome than any of the individual adipokines (14).

In humans, several single nucleotide polymorphisms (SNPs) have been identified in the LEP, LEPR, RETN, and ADIPOQ genes. The G-2548A polymorphism (rs7799039) in the LEP gene has been shown to affect leptin secretion in vitro and the strength of a complex formation with a nuclear protein (21). Studies about the effects of the SNP on leptin levels and obesity have been contradictory (21-26). The glutamine to arginine substitution (Q223R, rs1137101) in the LEPR gene lies within the first cytokine domain in the region encoding the extracellular domain of the leptin receptor and it has been shown to affect serum leptin-binding activity (27). In relation to the measures of body weight and insulin sensitivity, the Q223R polymorphism has been reported to explain $5 \%$ of the variance in percent fat mass and BMI (28) as well as insulin sensitivity (29). However, recent meta-analyses have not found any evidence for association of the Q223R polymorphism with the measures of obesity $(30,31)$.

The C-420G (rs1862513) SNP, in the promoter region of the RETN gene, has been associated with basal promoter activity in adipocytes and resistin mRNA levels in human abdominal s.c. fat (32). Several studies have found associations between the SNP and obesity, insulin sensitivity and insulin resistance (32-34). A high heritability has been observed for plasma adiponectin levels in French Caucasian families (35). Several investigators have characterized SNPs in the ADIPOQ gene and found one or more of these SNPs to be associated with adiponectin levels and obesity as well as with diabetes (35-38).

Here, we investigated the effect of SNPs in the adipokines on the CRC risk. We selected SNPs in the LEP, LEPR, RETN, and ADIPOQ genes based on their suggested effect on the gene expression or the protein function as described above. We investigated their association with the CRC risk in a Czech nationwide, hospital-based case-control population with 702 cases with histologically confirmed CRC and 752 controls with negative colonoscopic results for malignancy or idiopathic bowel diseases. Previously, we have studied the effect of SNPs in the INS, INSR, IGFB1, IRS1, and IRS 2 on CRC risk in the same population (39). As both insulin pathway and adipokines are associated with diabetes and obesity and adipokines directly affect insulin secretion (1), we additionally evaluated the effect of gene-gene interactions in these two groups of genes on the risk of $\mathrm{CRC}$.

\section{Materials and methods}

\section{Subjects}

The present hospital-based case-control study is based on incident cases recruited between September 2004 and February 2006. Cases were CRC patients visiting one of the nine oncological departments distributed in all geographic regions of the Czech Republic (two in Prague, one each in Benesov, Brno, Liberec, Ples, Pribram, Ústí nad Labem, and Zlín), thus representing the population of the entire country. During the study period, a total of 968 cases were diagnosed with CRC in these hospitals. Sixteen individuals were initially excluded, because they met the Amsterdam criteria I and II for hereditary CRC. This study includes 702 $(72.5 \%)$ patients, who provided biological samples of sufficient quality for genetic analysis. The lost cases were similar to those enrolled with respect to age and sex. All cases had positive colonoscopic results for malignancy, histologically confirmed as colon or rectal carcinomas.

Controls were recruited in the same period as the cases. They were subjects undergoing colonoscopy for various gastrointestinal complaints and in the frame of preventive examination in five large gastroenterological departments (Prague, Brno, Jihlava, Liberec, and Pribram). The distribution of controls from different parts of the Czech Republic was approximately the same as that of cases. The reasons for colonoscopic investigation were i) macroscopic bleeding, ii) positive fecal occult blood test (FOBT), and iii) abdominal pain of unknown origin. Owing to the high incidence of CRC in the Czech Republic, colonoscopy is largely recommended and practiced, and it is compulsory in case of positive FOBT. The most common findings for these subjects were hemorrhoids or idiopatic bowel diseases (IBD). Only subjects whose colonoscopic results were negative for malignancy, colorectal adenomas, benign polyps or IBD were chosen as controls. From 899 selected controls, $752(83.6 \%)$ accepted to participate, gave a blood sample and were analyzed in this study; the lost controls were similar to those included to the study with respect to age and sex. DNA was isolated from peripheral leucocytes within 4 weeks after the blood sample was collected using the standard proteinase $\mathrm{K}$ digestion, phenol/chloroform extraction and ethanol precipitation, and stored at $-80{ }^{\circ} \mathrm{C}$.

Study subjects provided information on their lifestyle habits (smoking, drinking, diet), BMI, diabetes and family/personal history of cancer, using structured questionnaires. Table 1 shows several characteristics of the study population at the time of recruitment. The median age of the cases was 62 (range 27-85) and of the controls 54 (range 29-91). Information on BMI at the time of diagnosis of cases and at the time of sample collection of the controls and on treatment for diabetes was available for $65.5 \%$ of cases and $66.9 \%$ of controls. 
Table 1 Selected characteristics of the study population.

\begin{tabular}{|c|c|c|c|}
\hline & Cases & Controls & $P$ value \\
\hline Total study population $(n)$ & 702 & 752 & \\
\hline Gender $(n(\%))$ & & & 0.59 \\
\hline Males & $400(57.0)$ & $439(58.4)$ & \\
\hline Females & $302(43.0)$ & $313(41.6)$ & \\
\hline Median age (years (range)) & $62(27-85)$ & $54(29-91)$ & $<0.0001$ \\
\hline Missing data $(n(\%))$ & $26(3.7)$ & $1(0.1)$ & \\
\hline Median BMI ( $\mathrm{kg} / \mathrm{m}^{2}$ (range)) & $26.5(13.1-44.9)$ & $26.4(16.6-44.3)$ & 0.79 \\
\hline Missing data $(n(\%))$ & $242(34.5)$ & $249(33.1)$ & \\
\hline Self-reported diabetes $(n(\%))$ & 73 (15.9) & $52(10.3)$ & 0.01 \\
\hline Missing data & $242(34.5)$ & $249(33.1)$ & \\
\hline Smoking status $(n(\%))$ & & & 0.97 \\
\hline Non-smoker & $343(53.3)$ & $220(53.1)$ & \\
\hline Ex-smoker $>5$ years & $151(23.3)$ & $91(22.0)$ & \\
\hline Ex-smoker $\leq 5$ years & $59(9.2)$ & $18(4.3)$ & \\
\hline Current smoker & $91(14.1)$ & 85 (20.5) & \\
\hline Missing data & $58(8.3)$ & $338(44.9)$ & \\
\hline Alcohol intake $(n(\%))$ & & & 0.05 \\
\hline No & $223(47.3)$ & $168(41.1)$ & \\
\hline Yes & $248(52.7)$ & $244(59.2)$ & \\
\hline Missing data & 231 (32.9) & 340 (45.2) & \\
\hline Diet $(n(\%))$ & & & 0.16 \\
\hline Vegetarian & $50(10.7)$ & $29(7.8)$ & \\
\hline Non-vegetarian & 418 (89.3) & 342 (92.2) & \\
\hline Missing data & 234 (33.3) & $381(50.7)$ & \\
\hline Place of residence $(n(\%))$ & & & 0.06 \\
\hline Town & $266(56.8)$ & $231(56.1)$ & \\
\hline Town+ country & $73(15.6)$ & $87(21.1)$ & \\
\hline Country & $129(27.6)$ & $94(22.8)$ & \\
\hline Missing data & $234(33.3)$ & 340 (45.2) & \\
\hline Education (n (\%)) & & & 0.02 \\
\hline Basic school & $158(33.8)$ & $105(25.5)$ & \\
\hline High school & $239(51.2)$ & $225(54.7)$ & \\
\hline University & $70(15.0)$ & $81(19.7)$ & \\
\hline Missing data & 235 (33.5) & 341 (45.3) & \\
\hline
\end{tabular}

BMI, body mass index; $n$, number of individuals.

For other variables, information was available for $\sim 67 \%$ of cases and $\sim 54 \%$ of controls. All participants gave informed written consent and the design of the study was approved by the Ethical Committee of the Institute of Experimental Medicine, Prague, Czech Republic.

\section{Genotyping using TaqMan assay}

The polymorphisms G-2548A (rs7799039) in the LEP gene, Q223R (rs1137101) in the LEPR gene, C-420G (rs1862513) in the RETN gene and C-11374G (rs266729) in the $A D I P O Q$ gene were investigated using the allelic discrimination method. TaqMan primers and probes were ordered as Assay-on-Demand (Assay ID: C__1328079_10, C__8722581_10, C_1394112_10, and C_2412786_10 for the LEP, LEPR, RETN, and ACDC genes respectively) from Applied Biosystems (Foster City, CA, USA). The reaction was performed in $5 \mu \mathrm{l}$ using $225 \mathrm{nM}$ each primer, $50 \mathrm{nM}$ each probe and $2.5 \mu \mathrm{l}$ TaqMan Universal $2 \times$ PCR Master Mix (Applied Biosystems) per reaction. PCR was performed at $50{ }^{\circ} \mathrm{C}$ for $2 \mathrm{~min}, 95^{\circ} \mathrm{C}$ for $10 \mathrm{~min}$ followed by $40-55$ cycles at $92{ }^{\circ} \mathrm{C}$ for $15 \mathrm{~s}$ and $60^{\circ} \mathrm{C}$ for $1 \mathrm{~min}$.
PCR was performed in a GeneAmp PCR System 9700 thermocycler and the number of cycles was dependent on the genotype clustering. The samples were read and analyzed on the ABI Prism 7900HT sequence detection system using SDS 1.2 software (Applied Biosystems).

\section{DNA sequencing}

About $10 \%$ of the genotyped samples were sequenced in order to verify the results obtained by TaqMan. All sequencing results were concordant with the original results. PCR amplification and sequencing reaction were performed as described previously (39).

\section{Statistical analysis}

The observed genotype frequencies in controls were tested for Hardy-Weinberg equilibrium (HWE). The best model to represent the relationship between the genotypes and the risk of CRC was selected based on likelihood ratio tests. Odds ratios (ORs) with 95\% confidence intervals (CIs) were estimated by logistic regression. Statistical significance for a different genotype distribution in cases versus controls was 
determined by two-sided global $\chi^{2}$ tests. The ORs were considered statistically significant when the $95 \%$ CIs did not include unity. With the present sample size, our study had a power of $78 \%$ to detect a per allele OR of 1.3 for a SNP with a minor allele frequency (MAF) of 26\% (the lowest MAF in the studied SNPs). The optimal combination of SNPs to describe the relationship between genotypes and risk of CRC was selected using Akaike's information criterion (AIC) (40). In our calculations, the lower the AIC value, the better the model. To identify possible high-order gene-gene interactions among the adipokine genes, multifactordimensionality reduction (MDR) followed by permutation analyses was applied (41). This method has been developed to detect and characterize combinations of multi-locus genotypes that are associated with a specific disease. Shortly, MDR classifies multi-locus genotypes into high-risk and low-risk groups. The advantages of assumed, and false-positive results due to multiple testing seem to be minimized.

\section{Results} were according to HWE in the control population. The allele and the genotype distributions shown in Table 2 were concordant with the previously published studies for Caucasians $(25,31-33,35,36,42)$ or for the CEPH (Utah residents with ancestry from northern and western Europe) population in the International HapMap Project (http://www.hapmap.org/index.html.en). Data on BMI and diabetes was available from $65.5 \%$ of CRC cases and $66.9 \%$ of controls (Table 1). Among them, the median BMI was practically identical in the cases (26.4) and the controls $(26.5 ; P=0.79)$, and the BMI did not depend on the genotypes (data not shown). Self-reported diabetes was more common among the CRC patients than the controls $(P=0.01)$, but the investigated SNPs did not seem to modify susceptibility to diabetes. Among the lifestyle factors, the cases seemed to have slightly lower education level than the the different percentage of missing data in cases $(33.5 \%)$ compared with controls (45.3\%). Age-adjusted ORs under the best model, selected by likelihood ratio tests, were calculated for each SNP. As shown in Table 2, only the RETN genotypes showed a trend to association with CRC with a global p-value of 0.06 and the per minor allele G OR of 1.18 (95\% CI 0.99-1.40). After additional adjustment for diabetes and education level, this association lost its statistical significance (OR 1.08, 95\% CI 0.87-1.34).

We used logistic regression and MDR to evaluate interactions between the cytokine genes genotyped in this study and the insulin-related genes genotyped in our previous study (39). Based on the case-control the method are that no mode of inheritance has to be

The genotype distributions of the four studied SNPs controls $(P=0.02)$, but this result may be influenced by

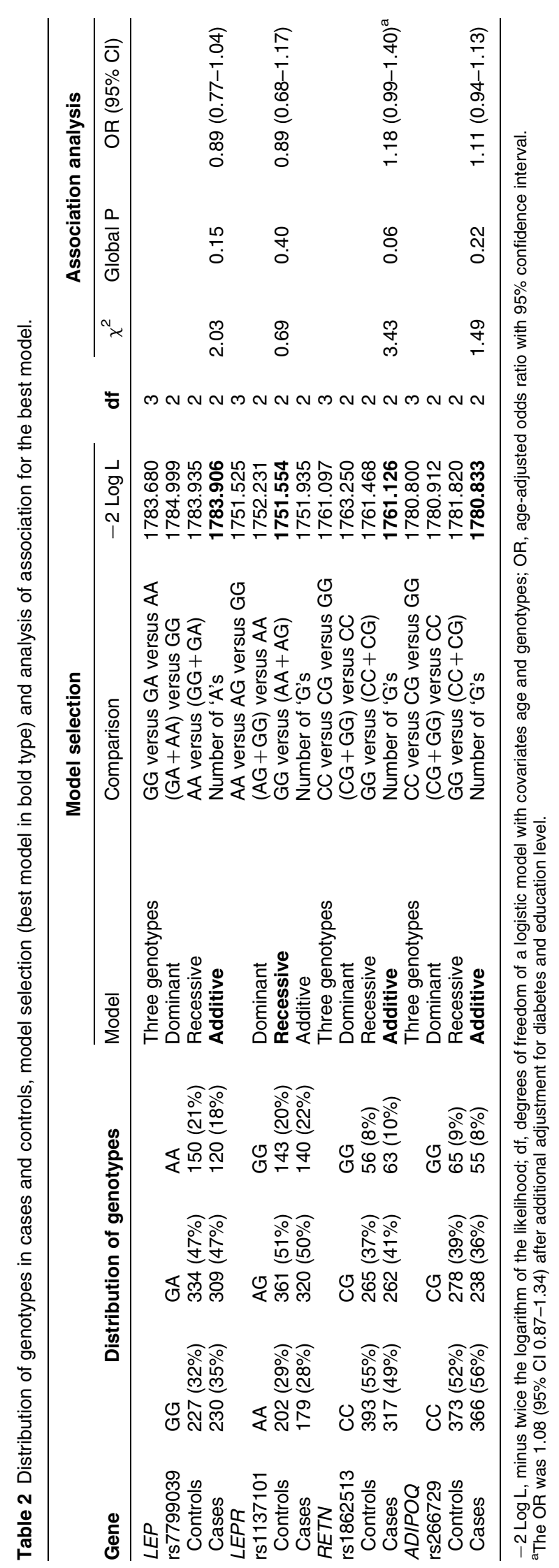

www.eje-online.org 
study design with three-genotype models for each SNP, statistically significant interactions were observed between the SNPs in the LEPR and the INS genes $(P$ value for multiplicative interaction 0.02$)$ and between the ADIPOQ and the INS genes ( $P$ value 0.03 ; Supplementary Table 1, which can be viewed online at http://www.eje-online.org/supplemental/). The MDR analysis confirmed this finding and indicated that the best model to describe the case/control distribution was based on variants of the LEPR and the INS genes (Fig. 1). Permutation analyses revealed the statistical significance of this classification $(P=0.02)$. Subsequent likelihood ratio tests and AIC values suggested a model with three variants for the LEPR gene and dominant effects for the INS gene (Supplementary Table 2, which can be viewed online at http://www.eje-online.org/ supplemental/). The association analysis indicated an increased CRC risk for carriers of the GG genotype of the LEPR gene and at least one variant allele of the INS gene compared with the carriers of the wild-type genotypes of these two SNPs (age-adjusted OR 1.64, 95\% CI 1.022.65; Fig. 1), the association was slightly stronger after additional adjustment for diabetes and education level (OR 2.04, 95\% CI 1.08-3.85). The MDR analysis confirmed this result and pointed to a complex interaction between the LEPR and the INS variants (Fig. 1, upper panel). The interaction between variants in the $A D I P O Q$ and the INS genes was also complex (Fig. 1, lower panel). Compared with the wild-type genotype carriers, carriers of the variant allele of the $A D I P O Q$ gene showed a decreased risk of CRC, when the INS genotype was CC (age-adjusted OR 0.73, 95\% CI 0.55-0.98), and when the INS genotype was TT (ageadjusted $0.37,95 \%$ CI $0.16-0.84$ ). However, the last association should be taken with caution, because of low numbers of cases $(n=9)$ and controls $(n=22)$ carrying the genotype combination. These associations did not remain statistically significant after additional adjustment for diabetes and education level (Fig. 1).

\section{Discussion}

Adipokines, secreted by the adipose tissue, are strong candidates for the link between obesity and risk of CRC $(1,6)$. In order to investigate the influence of potentially functional genetic variation in the adipokine genes LEP, LEPR, RETN, and ADIPOQ on the CRC risk, we genotyped SNPs in these genes in a cohort of cases and controls from the Czech Republic. As adipokines regulate the function of insulin pathway and we have previously studied the effect of insulin-related genes on CRC in the same population (39), gene-gene interactions between genes in the two pathways were also investigated.

It is well known that the curse of dimensionality diminishes the usefulness of traditional, parametric methods and that no single approach is optimal for all

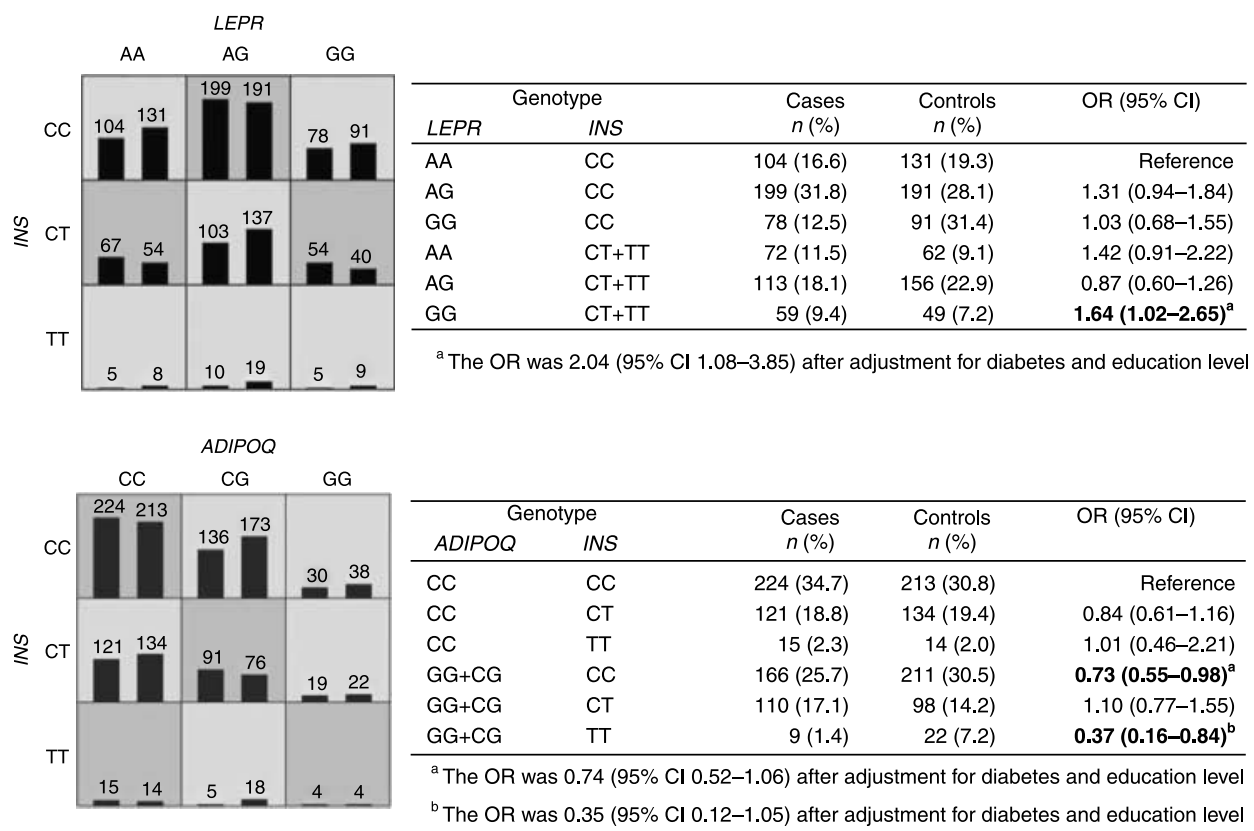

Figure 1 Interactions of $\angle E P R$ and INS as well as of $A D I P O Q$ and INS genotypes. On the left, the interactions according to multifactordimensionality reduction. The high risk genotype combinations (i.e., combinations with more cases than controls) are shown in dark grey boxes and the low risk combinations (with more controls than cases) in light grey boxes. In each box, left bars represent the number of cases and right bars the number of controls. On the right, distribution of the LEPR (rs1137101)-INS (rs3842754) genotype combinations and the ADIPOQ (rs266729)-INS (rs3842754) genotype combinations with age-adjusted odds ratios (ORs) and 95\% confidence intervals (Cls). The ORs were considered statistically significant, when the $95 \%$ Cls did not overlap unity, as indicated by bold. 
data scenarios $(43,44)$. For example, in stepwise logistic regression, the standard method for analysis of data from case-control studies, only interaction terms of variables with significant main effects are tested for significance $(45,46)$. Therefore, logistic regression lacks by definition the ability to characterize purely interactive effects. In complex diseases, such as CRC, a majority of genes may be difficult to identify due to their modest individual effects and complex interactions (47). Multidimensionality reduction was developed to detect genegene interactions in the presence or absence of main effects in case-control studies and we decided to apply also this method to analyze our data. The present logistic regression data suggested that SNPs in the LEPR and the ADIPOQ genes interact with the SNP in the INS gene at a statistically significant level, but the two genes did not show independent main effects. The possible interaction between LEPR and INS was shown by MDR analysis, which also selected this combination of genes to describe the distribution of cases and controls. Likelihood ratio tests and the values of the AIC indicated that the best model to represent CRC risk consisted of three genotypes for the LEPR SNP and a dominant penetrance model for the INS SNP. For the possible interaction between the $A D I P O Q$ and the INS genes the best model consisted of a dominant model for the $A D I P O Q$ SNP and a three genotype model for the INS gene.

The reported functional effects of the studied SNPs support our observations about a link between the SNPs in adiposity-related adipokines, in the insulin pathway and risk of CRC. The LEPR SNP Q223R has been shown to affect serum leptin-binding affinity, with individuals homozygous for the $\mathrm{R}$ allele having higher serum leptinbinding affinity than carriers of the $Q$ allele (27). Homozygosity for the $\mathrm{R}$ allele has also been associated with obesity and it has been reported to explain some $5 \%$ of the variance in percent fat mass and BMI (28). In another study, the $\mathrm{R}$ allele was associated with insulin sensitivity explaining about $6-7 \%$ of the variance in the trait (29). Since many studies, including two metaanalyses $(30,31)$, have failed to show an association with obesity phenotypes and the positive associations are mainly observed in young and/or healthy populations, Chiu et al. speculated that this SNP may contribute to the initiation events leading to insulin resistance (29). A part of the inter-individual variation in adiponectin levels may be explained by the $A D I P O Q$ promoter SNPs, including the C-11374G SNP (35). Although the low-level $-11374 \mathrm{G}$ allele has been associated with obesity, its association with diabetes seems to depend on the level of obesity $(35,36,38)$. The common partner of the gene-gene interactions observed in our study, the INS SNP + 1127INSPst1 (rs3842752) may regulate insulin production due to its location in the regulatory $3^{\prime}$-UTR (48) or due to its linkage disequilibrium with a variable number-tandem repeat (VNTR) locus in the promoter of the gene, which has consistently been associated with diabetes (49).

In the single SNP analysis, only the RETN SNP C-420G showed a trend to association with CRC risk based on an additive model (per allele OR 1.18; 95\% CI 0.99-1.40). In the recent study by Wågsäter et al. no statistically significant difference in the genotype distribution between the cases $(n=248)$ and the controls $(n=256)$ was observed, although the GG genotype was more common among the cases $(10.5 \%)$ than the controls $(6.3 \%)(17)$. The effect of the $\mathrm{G}$ allele is biologically plausible, because the $\mathrm{G}$ allele has been associated with both increased basal promoter activity and higher resistin mRNA levels in human abdominal s.c. fat as well as in insulin resistance and obesity $(32,33)$. An alternative mechanism linking RETN with CRC is through inflammation, a known risk factor for CRC (50), because in humans resistin has been shown to be produced mainly in the macrophages within the adipose tissue (9).

In addition to the report about the relationship between the RETN SNP C-420G and the risk of CRC (17), only one study has addressed the question of an association between genetic variation in the adipokine genes and the risk of CRC (51). In that study, a decreased risk for the AA genotype carriers of the SNP rs 2167270 in the $5^{\prime}$-UTR of the LEP gene was observed. Additionally, a decreased OR was observed for a combination of the LEP SNP rs21672709 and the SNP rs6588147, located in intron 2 of the LEPR gene. Slattery et al. (51) observed an interaction between the LEP and the LEPR SNPs and polymorphisms in the insulin-like growth factor-1 and the IRS2 genes. According to HapMap (http://www.hapmap.org/index. html.en) the SNP rs2167270 in the LEP gene is in a partial linkage disequilibrium with the SNP rs7799039 $\left(D^{\prime}=1.0, r^{2}=0.47\right)$ analyzed in our study, and the SNP rs6588147 in the LEPR gene shows low linkage disequilibrium with the SNP rs1137101 $\left(D^{\prime}=0.70\right.$, $\left.r^{2}=0.34\right)$ genotyped by us. Thus, although the SNPs studied by Slattery et al. (51) and by us are different and do not show high linkage disequilibrium with each other, both studies suggest an interaction of the adipokine and the INS-related genes in the etiology of CRC.

The strengths of our study include the relatively large sample size, 702 cases and 752 controls, and the selection of SNPs based on previous functional data. Additionally, we were able to study gene-gene interactions between genes in two obesity- and diabetes-related pathways, because the genotyping data on insulin-related genes in the same population were available from our previous study. The limitations of our study include the difference in age between the cases and the controls. However, no age or gender specific differences in the genotype distributions were observed. Another limitation was the presence of missing data on BMI, diabetes, and lifestyle habits, 
which may be related to work overload in some of the participating departments. Especially, for lifestyle habits, the answering rate was much lower among the controls (about 55\%) than among the cases (about 67\%). BMI data were recorded in the cases at the time of diagnosis and diabetes was self-reported, thus probably restricting the adequacy of this information. When individuals without information on age, genotype, diabetes or education were excluded from the analyses, the reduction in sample size resulted in non-significant associations. It should be kept in mind that different patterns of missing data in cases and controls may have resulted in spurious associations. Regarding the statistical methods used, it has been reported that standard methods for gene-gene interaction studies are not feasible and the results may be difficult to interpret (41). In our study, this was especially clear for the interaction between the $A D I P O Q$ and the INS genes, where both wild-type and variant homozygous genotypes of the INS gene together with at least one variant allele of the $A D I P O Q$ gene associated with decreased risk of CRC.

In conclusion, our results suggest that SNPs in the adipokine genes may affect the risk of CRC together with SNPs in other genes related to obesity or diabetes. This observation is relevant from both a practical and a scientific point of view and it warrants further studies using both large, independent cohorts, and a population-based approach.

\section{Declaration of interest}

There is no conflict of interest that could be perceived as prejudicing the impartiality of the research reported.

\section{Funding}

This study was supported by a grant from EU (LSHC-CT-2004503465). B Pardini, A Naccarati, L Vodickova, J Novotny, and P Vodicka were recipients of the following grants: GACR 310/07/1430 and IGA MZ NR8563-5/2005.

\section{References}

1 Calle EE \& Kaaks R. Overweight, obesity and cancer: epidemiological evidence and proposed mechanisms. Nature Reviews. Cancer 20044 579-591.

2 Moghaddam AA, Woodward M \& Huxley R. Obesity and risk of colorectal cancer: a meta-analysis of 31 studies with 70,000 events. Cancer Epidemiology, Biomarkers and Prevention 200716 2533-2547.

3 Austin MA, Friedlander Y, Newman B, Edwards K, Mayer-Davis EJ \& King MC. Genetic influences on changes in body mass index: a longitudinal analysis of women twins. Obesity Research 19975 326-331.

4 Rice T, Perusse L, Bouchard C \& Rao DC. Familial aggregation of body mass index and subcutaneous fat measures in the longitudinal Quebec family study. Genetic Epidemiology 199916 316-334.
5 Rankinen T, Zuberi A, Chagnon YC, Weisnagel SJ, Argyropoulos G, Walts B, Perusse L \& Bouchard C. The human obesity gene map: the 2005 update. Obesity $2006 \mathbf{1 4} 529-644$.

6 Trujillo ME \& Scherer PE. Adipose tissue-derived factors: impact on health and disease. Endocrine Reviews 200627 762-778.

7 Korner A, Bluher S, Kapellen T, Garten A, Klammt J, Kratzsch J \& Kiess W. Obesity in childhood and adolescence: a review in the interface between adipocyte physiology and clinical challenges. Hormones 20054 189-199.

8 Garofalo C \& Surmacz E. Leptin and cancer. Journal of Cellular Physiology 2006207 12-22.

9 Fantuzzi G. Adipose tissue, adipokines, and inflammation. Journal of Allergy and Clinical Immunology 2005115 911-919.

10 Hardwick JC, Van Den Brink GR, Offerhaus GJ, Van Deventer SJ \& Peppelenbosch MP. Leptin is a growth factor for colonic epithelial cells. Gastroenterology 2001121 79-90.

11 Rouet-Benzineb P, Aparicio T, Guilmeau S, Pouzet C, Descatoire V, Buyse M \& Bado A. Leptin counteracts sodium butyrateinduced apoptosis in human colon cancer HT-29 cells via NF-кB signaling. Journal of Biological Chemistry 2004279 16495-16502.

12 Stattin P, Lukanova A, Biessy C, Soderberg S, Palmqvist R, Kaaks R, Olsson T \& Jellum E. Obesity and colon cancer: does leptin provide a link? International Journal of Cancer 2004109 149-152.

13 Stattin P, Palmqvist R, Soderberg S, Biessy C, Ardnor B, Hallmans G, Kaaks R \& Olsson T. Plasma leptin and colorectal cancer risk: a prospective study in Northern Sweden. Oncology Reports 200310 2015-2021.

14 Stocks T, Lukanova A, Johansson M, Rinaldi S, Palmqvist R, Hallmans G, Kaaks R \& Stattin P. Components of the metabolic syndrome and colorectal cancer risk; a prospective study. International Journal of Obesity 200832 304-314.

15 Tamakoshi K, Toyoshima H, Wakai K, Kojima M, Suzuki K, Watanabe Y, Hayakawa N, Yatsuya H, Kondo T, Tokudome S, Hashimoto S, Suzuki S, Kawado M, Ozasa K, Ito Y \& Tamakoshi A. Leptin is associated with an increased female colorectal cancer risk: a nested case-control study in Japan. Oncology 200568 454-461.

16 Steppan CM, Bailey ST, Bhat S, Brown EJ, Banerjee RR, Wright CM, Patel HR, Ahima RS \& Lazar MA. The hormone resistin links obesity to diabetes. Nature 2001409 307-312.

17 Wagsater D, Mumtaz M, Lofgren S, Hugander A \& Dimberg J. Resistin in human colorectal cancer: increased expression independently of resistin promoter $-420 \mathrm{C}>\mathrm{G}$ genotype. Cancer Investigation 200826 1008-1014.

18 Ferroni P, Palmirotta R, Spila A, Martini F, Raparelli V, Fossile E, Mariotti S, Del Monte G, Buonomo O, Roselli M \& Guadagni F. Prognostic significance of adiponectin levels in non-metastatic colorectal cancer. Anticancer Research 200727 483-489.

19 Wei EK, Giovannucci E, Fuchs CS, Willett WC \& Mantzoros CS. Low plasma adiponectin levels and risk of colorectal cancer in men: a prospective study. Journal of the National Cancer Institute 200597 1688-1694.

20 Lukanova A, Soderberg S, Kaaks R, Jellum E \& Stattin P. Serum adiponectin is not associated with risk of colorectal cancer. Cancer Epidemiology, Biomarkers and Prevention 200615 401-402.

21 Hoffstedt J, Eriksson P, Mottagui-Tabar S \& Arner P. A polymorphism in the leptin promoter region $(-2548 \mathrm{G} / \mathrm{A})$ influences gene expression and adipose tissue secretion of leptin. Hormone and Metabolic Research 200234 355-359.

22 Le Stunff C, Le Bihan C, Schork NJ \& Bougneres P. A common promoter variant of the leptin gene is associated with changes in the relationship between serum leptin and fat mass in obese girls. Diabetes 200049 2196-2200.

23 Li WD, Reed DR, Lee JH, Xu W, Kilker RL, Sodam BR \& Price RA. Sequence variants in the $5^{\prime}$ flanking region of the leptin gene are associated with obesity in women. Annals of Human Genetics 1999 $63227-234$. 
24 Mammes O, Betoulle D, Aubert R, Giraud V, Tuzet S, Petiet A, Colas-Linhart N \& Fumeron F. Novel polymorphisms in the $5^{\prime}$ region of the LEP gene: association with leptin levels and response to low-calorie diet in human obesity. Diabetes $1998 \mathbf{4 7} 487-489$.

25 Mammes O, Betoulle D, Aubert R, Herbeth B, Siest G \& Fumeron F. Association of the G-2548A polymorphism in the $5^{\prime}$ region of the LEP gene with overweight. Annals of Human Genetics $20006 \mathbf{4}$ 391-394.

26 Portoles O, Sorli JV, Frances F, Coltell O, Gonzalez JI, Saiz C \& Corella D. Effect of genetic variation in the leptin gene promoter and the leptin receptor gene on obesity risk in a population-based case-control study in Spain. European Journal of Epidemiology 2006 21 605-612.

27 Quinton ND, Lee AJ, Ross RJ, Eastell R \& Blakemore AI. A single nucleotide polymorphism (SNP) in the leptin receptor is associated with BMI, fat mass and leptin levels in postmenopausal Caucasian women. Human Genetics 2001108 233-236.

28 Yiannakouris N, Yannakoulia M, Melistas L, Chan JL, KlimisZacas D \& Mantzoros CS. The Q223R polymorphism of the leptin receptor gene is significantly associated with obesity and predicts a small percentage of body weight and body composition variability. Journal of Clinical Endocrinology and Metabolism 2001 86 4434-4439.

29 Chiu KC, Chu A, Chuang LM \& Saad MF. Association of leptin receptor polymorphism with insulin resistance. European Journal of Endocrinology 2004150 725-729.

30 Heo M, Leibel RL, Fontaine KR, Boyer BB, Chung WK, Koulu M, Karvonen MK, Pesonen U, Rissanen A, Laakso M, Uusitupa MI, Chagnon Y, Bouchard C, Donohoue PA, Burns TL, Shuldiner AR, Silver K, Andersen RE, Pedersen O, Echwald S, Sorensen TI, Behn P, Permutt MA, Jacobs KB, Elston RC, Hoffman DJ, Gropp E \& Allison DB. A meta-analytic investigation of linkage and association of common leptin receptor (LEPR) polymorphisms with body mass index and waist circumference. International Journal of Obesity and Related Metabolic Disorders 200226 640-646.

31 Paracchini V, Pedotti P \& Taioli E. Genetics of leptin and obesity: a HuGE review. American Journal of Epidemiology 2005162 101-114.

32 Smith SR, Bai F, Charbonneau C, Janderova L \& Argyropoulos G. A promoter genotype and oxidative stress potentially link resistin to human insulin resistance. Diabetes 200352 1611-1618.

33 Engert JC, Vohl MC, Williams SM, Lepage P, Loredo-Osti JC, Faith J, Dore C, Renaud Y, Burtt NP, Villeneuve A, Hirschhorn JN, Altshuler D, Groop LC, Despres JP, Gaudet D \& Hudson TJ. 5' Flanking variants of resistin are associated with obesity. Diabetes 200251 1629-1634.

34 Wang H, Chu WS, Hemphill C \& Elbein SC. Human resistin gene: molecular scanning and evaluation of association with insulin sensitivity and type 2 diabetes in Caucasians. Journal of Clinical Endocrinology and Metabolism $2002872520-2524$.

35 Vasseur F, Helbecque N, Dina C, Lobbens S, Delannoy V, Gaget S, Boutin P, Vaxillaire M, Lepretre F, Dupont S, Hara K, Clement K, Bihain B, Kadowaki T \& Froguel P. Single-nucleotide polymorphism haplotypes in the both proximal promoter and exon 3 of the APM1 gene modulate adipocyte-secreted adiponectin hormone levels and contribute to the genetic risk for type 2 diabetes in French Caucasians. Human Molecular Genetics 200211 2607-2614.

36 Bouatia-Naji N, Meyre D, Lobbens S, Seron K, Fumeron F, Balkau B, Heude B, Jouret B, Scherer PE, Dina C, Weill J \& Froguel P. ACDC/adiponectin polymorphisms are associated with severe childhood and adult obesity. Diabetes 200655 545-550.
37 Pollin TI, Tanner K, O'Connell JR, Ott SH, Damcott CM, Shuldiner AR, McLenithan JC \& Mitchell BD. Linkage of plasma adiponectin levels to $3 \mathrm{q} 27$ explained by association with variation in the APM1 gene. Diabetes 200554 268-274.

38 Vasseur F, Helbecque N, Lobbens S, Vasseur-Delannoy V, Dina C, Clement K, Boutin P, Kadowaki T, Scherer PE \& Froguel P. Hypoadiponectinaemia and high risk of type 2 diabetes are associated with adiponectin-encoding (ACDC) gene promoter variants in morbid obesity: evidence for a role of ACDC in diabesity. Diabetologia $2005 \mathbf{4 8} 892-899$.

39 Pechlivanis S, Pardini B, Bermejo JL, Wagner K, Naccarati A, Vodickova L, Novotny J, Hemminki K, Vodicka P \& Forsti A. Insulin pathway related genes and risk of colorectal cancer: INSR promoter polymorphism shows a protective effect. EndocrineRelated Cancer 2007 14 733-740.

40 Akaike $H$. Information theory and an extension of the maximum likelihood principle. Second International Symposium on Information Theory Budapest Akademiai Kiado 1973 pp 267-281.

41 Ritchie MD, Hahn LW, Roodi N, Bailey LR, Dupont WD, Parl FF \& Moore JH. Multifactor-dimensionality reduction reveals highorder interactions among estrogen-metabolism genes in sporadic breast cancer. American Journal of Human Genetics 200169 138-147.

42 Conneely KN, Silander K, Scott LJ, Mohlke KL, Lazaridis KN, Valle TT, Tuomilehto J, Bergman RN, Watanabe RM, Buchanan TA, Collins FS \& Boehnke M. Variation in the resistin gene is associated with obesity and insulin-related phenotypes in Finnish subjects. Diabetologia 200447 1782-1788.

43 Marchini J, Donnelly P \& Cardon LR. Genome-wide strategies for detecting multiple loci that influence complex diseases. Nature Genetics 200537 413-417.

44 Motsinger-Reif AA, Reif DM, Fanelli TJ \& Ritchie MD. A comparison of analytical methods for genetic association studies. Genetic Epidemiology 200832 767-778.

45 Bermejo JL \& Hemminki K. Gene-environment studies: any advantage over environmental studies? Carcinogenesis $2007 \mathbf{2 8}$ $1526-1532$.

46 Cordell HJ \& Clayton DG. A unified stepwise regression procedure for evaluating the relative effects of polymorphisms within a gene using case/control or family data: application to HLA in type 1 diabetes. American Journal of Human Genetics 200270 124-141.

47 Lusis AJ, Attie AD \& Reue K. Metabolic syndrome: from epidemiology to systems biology. Nature Reviews. Genetics 2008 9 819-830.

48 Ho GY, Melman A, Liu SM, Li M, Yu H, Negassa A, Burk RD, Hsing AW, Ghavamian R \& Chua SC Jr. Polymorphism of the insulin gene is associated with increased prostate cancer risk. British Journal of Cancer $2003 \mathbf{8 8} 263-269$.

49 Bennett ST \& Todd JA. Human type 1 diabetes and the insulin gene: principles of mapping polygenes. Annual Review of Genetics $199630343-370$.

50 Coussens LM \& Werb Z. Inflammation and cancer. Nature 2002 420 860-867.

51 Slattery ML, Wolff RK, Herrick J, Caan BJ \& Potter JD. Leptin and leptin receptor genotypes and colon cancer: gene-gene and genelifestyle interactions. International Journal of Cancer $2008 \mathbf{1 2 2}$ 1611-1617.

Received 26 February 2009

Accepted 8 March 2009 